\title{
Treponema-specific and antilipoidal 19S(IgM) antibodies in penicillin-treated and untreated rabbits after infection with Treponema pallidum
}

\author{
F MÜLLER AND S OELERICH \\ From the Division of Serology, Department of Medical Microbiology, Institute of Hygiene, Hamburg, \\ West Germany
}

SUMMARY The titres of treponema-specific and antilipoidal 19S(IgM) antibodies were determined in rabbits infected intratesticularly with Treponema pallidum. One group of rabbits was treated with penicillin the other served as control. Using different serological tests it was shown that 19S(IgM) antibodies were still detectable eight months after infection at about the same titres in both groups. In contrast, 19S(IgM) antibody titres in patients with syphilis became undetectable within three to six months after penicillin treatment. It is suggested therefore that the rabbit is not a reliable model for studying the effect of penicillin in human $T$ pallidum infections.

\section{Introduction}

Since the experiments of Haensell ${ }^{1}$ and Parodi ${ }^{2}$ the rabbit has been the animal of choice in research into syphilis. Thus, experimentally infected rabbits have been widely used to test the various antisyphilitic drugs, including penicillin. ${ }^{3}$

The presence of Treponema pallidum in the tissues of infected rabbits after penicillin treatment is difficult to prove. The results of staining methods are uncertain because differentiation between $T$ pallidum and Treponema cuniculi is often impossible.

In previous investigations several authors have suggested that the demonstration of antigen-specific $19 \mathrm{~S}(\mathrm{IgM})$ antibodies is a reliable indicator of the persistence of antigen in the host. This suggestion was observed in viral infections ${ }^{45}$ and in syphilis by Atwood and Miller, ${ }^{6} \mathrm{O}^{\prime} \mathrm{Neill}$ and Nicol, ${ }^{7}$ Müller and Loa, ${ }^{8}$ and Schmidt. ${ }^{9}$ It should be possible therefore to study the effect of penicillin treatment on the elimination of $T$ pallidum in infected rabbits using the decrease in treponema-specific 19S(IgM) antibodies as an indicator. Furthermore, the titres of 19S(IgM) antibodies after penicillin treatment should indicate whether or not the immunological reaction of the infected rabbit is comparable to that of man.

Address for reprints: Professor F Müller, Hygiene-Institut, GorchFock-Wall 15/17, D-2000 Hamburg 36, Federal Republic of Germany

Accepted for publication 11 August 1980

\section{Material and methods}

INFECTION OF RABBITS

Eighteen male albino rabbits weighing between 2 and $2.5 \mathrm{~kg}$ were used. Their sera were tested for antilipoidal as well as for treponema-specific antibodies by the cardiolipin complement-fixation (CF) test, the $T$ pallidum haemagglutination assay (TPHA), and the fluorescent treponemal antibody (FTA) test and gave negative results. One uninfected animal served as control throughout the experiment.

Seventeen animals were infected with $T$ pallidum (Nichols strain). Under ether anaesthesia $2 \mathrm{ml}$ of a suspension containing about $5 \times 10^{6}$ treponemes $/ \mathrm{ml}$ were injected into the testicles (a total dose of about $1 \times 10^{7}$ treponemes. The rabbits developed a typical orchitis between the seventh and tenth day after infection.

\section{TREATMENT}

Eight of the animals were treated from day 21 to day 36 after infection with hydracillin, containing 0.75 megaunits procaine penicillin $G$ and 0.25 megaunits penicillin $G$ sodium per $2 \mathrm{ml}$. The rabbits received $0.3 \mathrm{ml}$ hydracillin intramuscularly (that is, 0.15 megaunits of the penicillin preparation). In $T$ pallidum immobilisation (TPI) tests with heated guinea pig serum, and using controls with defined penicillin concentrations, it could be shown that the serum penicillin concentration was more than $0.03 \mathrm{IU} / \mathrm{ml}$ in the rabbits' sera for 20 days. 
Under pentobarbital narcosis, blood samples were collected by cardiac puncture at one, two, three, and eight months after infection. The sera were inactivated for 30 minutes at $56^{\circ} \mathrm{C}$ in a waterbath and tested on the day of collection or the following day after storage at $4^{\circ} \mathrm{C}$. The room temperature for the animals was $22^{\circ} \mathrm{C}$ throughout the experiment.

\section{SEPARATION OF GLOBULIN FRACTIONS (GEL FILTRATION)}

The separation of the 19S(IgM) fraction of the rabbits' sera was performed either by Sephadex G $200^{810}$ or by Ultrogel AcA $34^{11}$ using samples of $0.7 \mathrm{ml}$ serum and columns $40 \mathrm{~cm}$ long and $1.5 \mathrm{~cm}$ in diameter. Phosphate-buffered saline ( $\mathrm{pH} 7 \cdot 3 ; 15 \mathrm{mS}$ conductivity at $22^{\circ} \mathrm{C}$ ) was used as eluant.

\section{ESTIMATION OF ANTIBODY TITRES}

Titres of the 19S(IgM) antibodies in the different tests were calculated from three peak fractions (each $1 \cdot 3 \mathrm{ml}$ ) of the first elution maximum of the column. The fractions were not concentrated. Using immunofluorescence and $7 \mathrm{~S}(\mathrm{IgG})$-specific anti-rabbit serum (from goats) no 7S(IgG) antibodies were found in the 19S(IgM) fractions.

\section{INDIRECT HAEMAGGLUTINATION}

The TPHA was performed quantitatively on whole sera as well as on the fractions after gel filtration following the manufacturer's instructions (Fujizoki Pharmaceuticals Co Ltd, Tokyo).

\section{INDIRECT IMMUNOFLUORESCENCE}

The standard method for the quantitative FTA test was used. ${ }^{12}$ Twofold dilutions were tested, starting with a dilution of $1 / 5$ in sera and $1 / 2$ in the fractions after gel filtration. No absorption by ultrasonicate of Treponema phagedenis was carried out because the animals had no treponema-specific antibodies at the time the experiments were started. Treponemal infections other than with $T$ pallidum (Nichols strain) could, furthermore, be excluded by parallel investigations of the uninfected control animal.

For demonstration of treponema-specific antibodies an FITC-labelled polyvalent anti-rabbit globulin serum (from goats) was used (Deutsche BioMérieux GmbH, Nürtingen, lot No 01106) at a dilution of $1 / 30$. An anti-rabbit IgM serum with $\mu$-chain specificity was prepared in guinea pigs in our laboratory after the method of Fink et $\mathrm{al}^{13}$ and was conjugated with FITC by the method of Wagner and Heinrich. ${ }^{14}$ Unfixed FITC was removed from the serum by filtration through Sephadex G 25 . Finally, the anti-rabbit IgM serum was absorbed with rabbit IgG. This preparation was used for the 19S-IgMFTA-ABS test in the fractions after gel filtration at a dilution of $1 / 20$. Working dilutions of conjugates $\frac{O}{\varphi}$ were established by titration.

ANTILIPOIDAL CF TEST

For the CF test, with cardiolipin as antigen, a microtitre Kolmer technique was used. ${ }^{9}$

\section{Results}

TPHA TEST

The antibody titres in the different tests of sera from $\vec{O}$ eight treated and nine untreated rabbits after intra- $\rightarrow$ testicular infection with $T$ pallidum are expressed as $\vec{\omega}$ mean values at the different times of cardiac $\frac{O}{\infty}$ puncture (figs 1-4). All infected animals developed

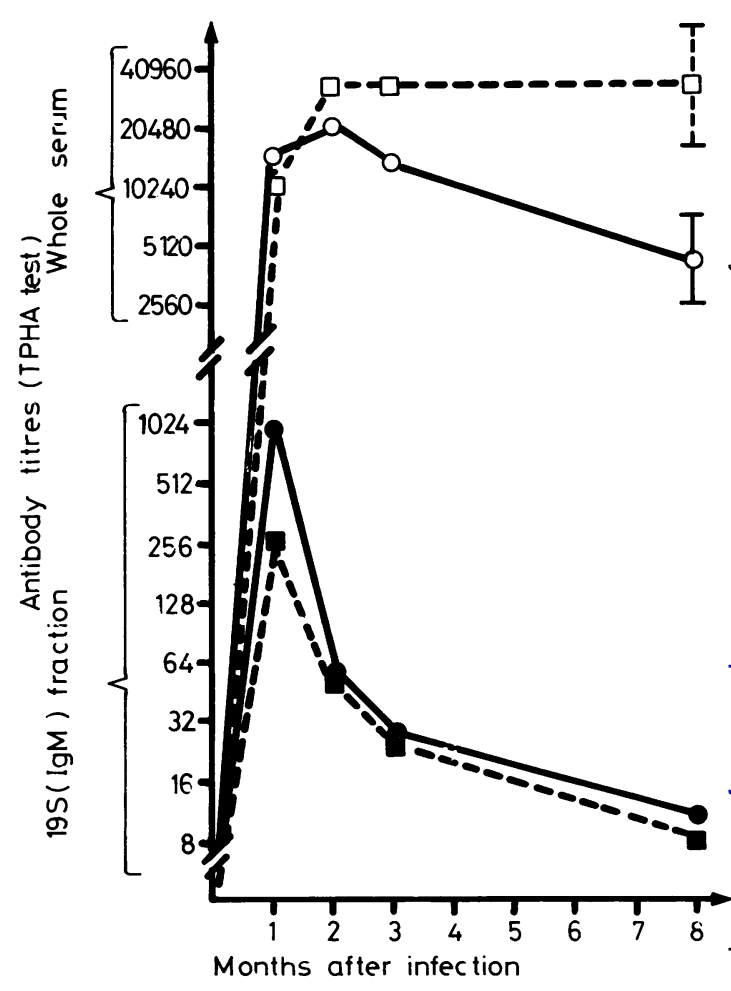

FIG 1 TPHA antibody titres in whole serum and in the 19S(IgM) fraction after gel filtration of penicillin-treated or untreated rabbits infected with $T$ pallidum (Nichols strain).

$\square----\square$ Mean titres in whole serum of untreated rabbits.

Mean titres in whole serum of rabbits after penicillin treatment. (The decrease in titre has to be interpreted as a random result.) $\square-D_{-}$Mean titres of 19S(IgM) antibodies in the first elution peak after gel filtration of serum of untreated rabbits. $\longrightarrow$ Mean titres of 19S(IgM) antibodies in the first elution peak after gel filtration of rabbit serum after penicillin treatment. 
treponema-specific antibodies (reactive in the TPHA test) with high titres (between $1 / 2560$ and $1 / 81$ 920) (fig 1). The mean was estimated to be more than $1 / 20000$. In the following eight months the TPHA test titre remained high in the untreated group and fell to a mean of about $1 / 4000$ in the treated group.

The 19S(IgM) TPHA antibody titres in the peak fractions showed a nearly analogous pattern in treated and untreated rabbits. Antibodies of this type, with titres between $1 / 8$ and $1 / 16$, persisted in both groups of animals for as long as eight months after infection.

\section{IMMUNOFLUORESCENCE TESTS}

A comparable response of antibody development was demonstrated in the treated and untreated rabbits by the FTA and 19S-IgM-FTA tests (fig 2). A high increase in $19 \mathrm{~S}(\mathrm{IgM})$ antibodies after infection was followed by a rapid decrease in the following three months. Five months later $19 \mathrm{~S}(\mathrm{IgM})$ antibodies were still demonstrable by the 19S-IgM-FTA test at titres of about $1 / 5$ in treated as well as in untreated animals.

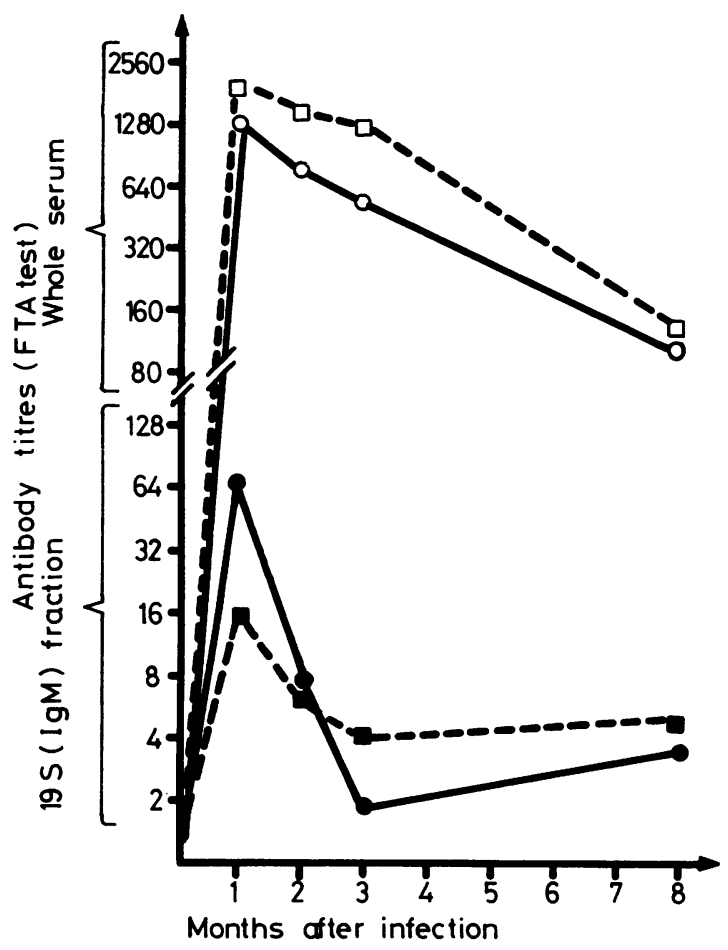

FIG 2 FTA test titres in whole serum and in the 19S(IgM) fraction after gel filtration of penicillin-treated or untreated rabbits infected with $T$ pallidum (Nichols strain. (For symbols of the curves see fig 1.)
CF TEST

Similarly, complement-fixing antilipoidal antibodies rose to mean titres of $1 / 3000$ or $1 / 1000$ in the first month after infection and decreased to between $1 / 16$ and $1 / 32$ at the eighth munth after infection (fig 3). 19S(IgM) antilipoidal antibodies still persisted in both groups at a titre of about $1 / 6$ at the end of the experiment.

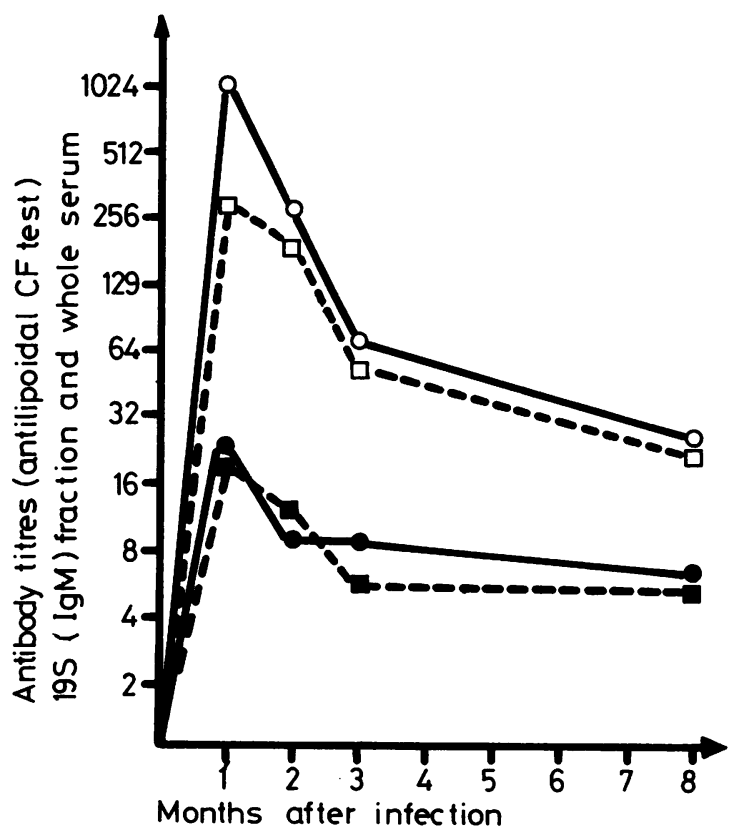

FIG 3 Antilipoidal CF antibody titres in whole serum and in the 19S(IgM) fractions after gel filtration of penicillin-treated or untreated rabbits infected with $T$ pallidum (Nichols strain). (For symbols of the curves see fig l.)

CONTROL

The uninfected control rabbit developed neither treponema-specific nor antilipoidal antibodies during the observation period of eight months.

\section{HUMAN SYPHILIS}

For comparison the antibody reaction of patients with treated or untreated primary syphilis (demonstrated by the $19 \mathrm{~S}$ (IgM) or 7S(IgG) FTA-ABS test) is shown in fig 4. Treatment with penicillin (1 megaunit clemizol penicillin intramuscularly for 12 consecutive days) resulted in a decrease in $19 \mathrm{~S}(\mathrm{IgM})$ antibodies to an undetectable level within three to six 


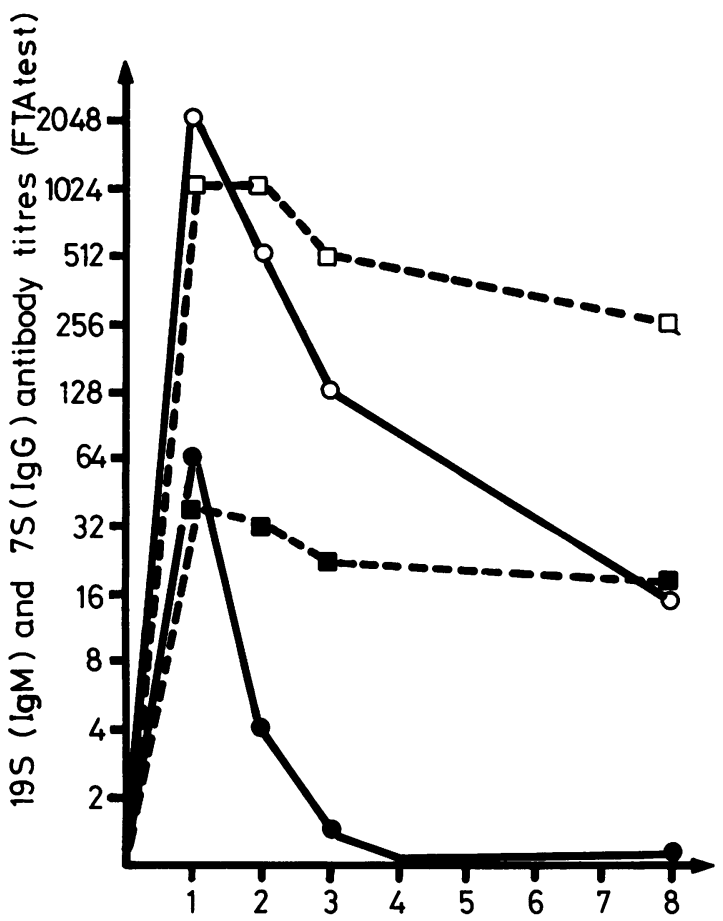

Months after infection

FIG 4 19S(IgM) and 7S(IgG) antibody titres in patients with penicillin-treated or untreated primary syphilis. $\square----\square$ Treponema-specific 7S(IgG) antibodies of an untreated patient with primary syphilis. $\bigcirc$ Treponema-specific $7 S(\mathrm{IgG})$ antibodies of a patient with primary syphilis after penicillin treatment. Treponema-specific 19S(IgM) antibodies of an untreated patient with primary syphilis. $\longrightarrow$ Treponemaspecific 19S(IgM) antibodies of a patient with primary syphilis after penicillin treatment.

months; this type of antibody as well as the $7 \mathrm{~S}(\mathrm{IgG})$ type might persist in untreated patients for more than eight months. Details of our investigations of the effect of treatment with penicillin or other antibiotics in human syphilis will be published later.

\section{Discussion}

The immune response to intratesticular infection of rabbits with $T$ pallidum is not affected by therapeutically effective treatment with penicillin (about $50000 \mathrm{IU} / \mathrm{kg} /$ body weight daily). Eight months after infection and about seven months after treatment there were no differences in the titres of 19S(IgM) antibodies in treated and untreated rabbits by the different tests.
Using the TPHA and the FTA and antilipoidal CF tests it was shown that in treated as well as in untreated animals a high increase of 19S(IgM) antibodies was followed by a decrease to a low level at eight months after infection.

From the immunological point of view it might be suggested that the identical immune response of $\vec{\circ}$ treated and untreated rabbits shows an equivalent $\vec{\overrightarrow{ }}$ stage of chronic or healed infection. Investigations in $\underset{\sigma}{\omega}$ patients with syphilis led to the suspicion that the of demonstration of treponema-specific 19S(IgM) $\mathrm{G}$. antibodies by the immunofluorescence technique is a sign that pathogenic treponemes persist in the host. ${ }^{6-9}$ This has not been adequately proved in experimental syphilis in rabbits.

Our results in no way contradict those of Paris- $\vec{T}$ Hamelin et al. ${ }^{15}$ These authors estimated 19S(IgM) $\mathbb{D}$ antibodies using the FTA test and TPHA at dilutions of $1 / 100$ and $1 / 40$ respectively and so were not able to detect the low titres of 19S(IgM) antibodies.

The observations made on $19 \mathrm{~S}$ (IgM) antibodies in $\vec{\oplus}$ typical cases of primary syphilis in man after.penicillin treatment differ from those in experimentally infected rabbits. In cured patients treponema-specific $19 \mathrm{~S}(\mathrm{IgM})$ antibodies disappeared $\bar{O}$ between three and six months after treatment had started. In contrast, this type of antibody can persist $\stackrel{\AA}{\AA}$ in the serum of untreated patients for eight months or longer.

The reasons for the different immunological $\vec{\partial}$ reactions to penicillin treatment for syphilis in humans and rabbits are not known. Nevertheless, from the results of our experiments we suggest that the rabbit is an unsuitable model for studies of the effect of penicillin in human syphilis.

\section{References}

1. Haensell P. Vorläufige Mittheilung über Versuche von o Impfsyphilis der Iris und Cornea des Kaninchenauges. Arch $\mathrm{N}$ Ophthalmol 1881;27:93-100.

2. Parodi U. Sulla trasmissione della sifilide al testicole del N coniglio. G Accad Med Torino 1907; 13:288.

3. Willcox RR, Guthe T. Treponema pallidum. A bibliographical review of the morphology, culture and survival of $T$ pallidum 0 and associated organisms. Bull WHO 1966;35 suppl No 1 .

4. Schmitz $H$, Haas $R$. Zytomegalievirus-Erkrankungen bei $\mathbb{D}$ Erwachsenen. Dtsch Med Wochenschr 1973;98:649-53.

5. Schmitz H, Volz D, Krainick-Riechert C, Scherer M. Acute Epstein-Barr virus infections in children. Med Microbiol Immunol (Berl) 1972; 158: 58-63.

6. Atwood, WG, Miller JL. Fluorescent treponemal antibodies in $\mathbb{D}$ fractionated syphilitic sera. Arch Dermatol 1969; 100:763-9.

7. O'Neill $\mathbf{P}$, Nicol CS. IgM class antitreponemal antibody in treated and untreated syphilis. Br J Vener Dis 1972; 48:460-3. $\sigma$

8. Müller F, Loa PL. Neue Möglichkeiten in der immunologischen Diagnostik der Treponemen-infektion (Syphilis). Infection 1974;2: 127-31.

9. Schmidt B. The 19S-IgM-FTA-ABS test in the serum diagnosis of syphilis. WHO/VDT/RES 79.362 . 
10. Müller F. Zur Technik des Nachweises treponemenspezifischer 19S-IgM-Antikörper bei der latenten und spätlatenten Syphilis. Immun Infekt 1977; 5:109-13.

11. Müller F, Oelerich S. Ein modifiziertes Verfahren des IgMFTA-19S-Tests zum Nachweis kompetitiv gehemmter Antikörper bei der Syphilis. Ärztl Lab 1978; 24:386-91.

12. United States Department of Health, Education and Welfare. Manual of Tests for Syphilis Public Health Service publication No 411. Atlanta, Georgia: US Department of Health, Education and Welfare, 1969.

13. Fink EH, Oelerich S, zum Felde I. Antikörpernachweis und quantitative Bestimmung der Serum IgM bei der experimentellen Trypanosomiasis des Meerschweinchens. $Z$ Tropenmed Parasitol 1971;22:343-50.
14. Wagner $M$, Heinrich $H$, Zum fluoreszenz-serologischen Nachweis von Streptokokken der Gruppe A Zentralbl Bakteriol (Orig A) 1962; 186:292-302.

15. Paris-Hamelin A, Vaisman A, Fustec-Ibarboure S, Montezin M. Courbes d'évolution des anticorps IgM et IgG dans la syphilis venerienne chez l'homme et dans les tréponématoses expérimentales. WHO/VDT/RES 78.357. 